\title{
Sapieżyńska ochrona dóbr Potockich w starostwie owruckim w latach 80. i 90. XVII wieku Przyczynek do badań nad współpracą rodzin magnackich w czasach panowania Jana III Sobieskiego*
}

\begin{abstract}
Abstrakt: Sapiehowie i Potoccy byli jednymi z najbardziej wpływowych rodzin w dawnej Rzeczypospolitej. Druga z wymienionych familii posiadała liczne dobra na Ukrainie, które rujnowały częste przemarsze żołnierzy litewskich. Władzę nad nimi sprawował hetman wielki Kazimierz Jan Sapieha. Zasadniczym celem artykułu jest rozpatrzenie kwestii dotyczącej możliwej ochrony przez hetmana Sapiehę dóbr Potockich w zamian za ich głosy poparcia na sejmie i obronę w czasie ataków na litewskiego dowódcę wywołanych jego absencją pod Wiedniem.
\end{abstract}

Słowa kluczowe: Sapiehowie, Potoccy, majątki, Ukraina, wojsko

Potoccy to jedna z najważniejszych rodzin w historii dawnej, szlacheckiej Rzeczypospolitej. Jej przedstawiciele zajmowali najważniejsze stanowiska w centralnej i terenowej administracji państwowej oraz posiadali ogromny majątek, dzięki któremu odgrywali istotną rolę w życiu politycznym i społeczno-gospodarczym państwa, a następnie ziem polsko-litewskich w XIX stuleciu. Apogeum świetności Potockich przypada na XVIII wiek, co znalazło potwierdzenie także w dokumentach dyplomatów francuskich, którzy opisali najważniejsze rodziny w Rzeczypospolitej.

* Artykuł jest w części wynikiem badań naukowych związanych z realizacją grantu Narodowego Centrum Nauki w Krakowie nr DEC 2017/01/X/HS3/00482 na realizację pojedynczego działania naukowego pt. „Elity społeczno-polityczne Wielkiego Księstwa Litewskiego w świetle raportów dyplomatów francuskich i angielskich w II połowie XVII wieku". 
W odniesieniu do tej familii już w pierwszym zdaniu podkreślono, że „cette maison est illustre et nombreuse”. Ród ich został wymieniony w gronie Czartoryskich, Radziwiłłów, Tyszkiewiczów, Massalskich oraz Sapiehów. W przypadku ostatnich z wymienionych politycy wersalscy zaznaczyli, że jest to rodzina, która została prawie zrujnowania w czasach panowania Augusta II. To niezwykle interesująca uwaga osoby sporządzającej dokument, biorąc pod uwagę jego datację, czyli rok 1751. Od bitwy olkienickiej, regularnej i zaplanowanej grabieży majątków sapieżyńskich, minęło już wówczas sporo czasu, a mimo tego we Francji doskonale o tym pamiętano, a przede wszystkim znano skalę zjawiska. Dowodzi to również temu, że przez tak długi czas Sapiehowie nie umieli do końca przezwyciężyć problemów majątkowych, które rozpoczęły się w pierwszej dekadzie XVIII wieku, o czym także wiedzieli politycy w Wersalu. Interesujące jest, że obserwatorzy polsko-litewskiej sceny politycznej znad Sekwany zaliczyli Sapiehów do grona bliskich przyjaciół Potockich ${ }^{1}$.

Konflikty zbrojne, szczególnie te toczące się w czasach panowania Jana III Sobieskiego, skutkowały częstymi przemarszami wojskowych przez Ukrainę, a ściślej przez Podole, gdzie leżały kompleksy dóbr Potockich. Również tam oddziały wojskowe miały wyznaczone miejsca koncentracji i przez te tereny wracały po udanych bądź nie - kampaniach wojennych do Wielkiego Księstwa Litewskiego lub Korony Polskiej. Na ziemiach tych - ze względu na bliskość teatru działań wojennych - jednostki wojskowe otrzymywały również leża zimowe i prawo wybierania przez żołnierzy hibern (chlebów zimowych). Często zatem nieopłaceni i niezdyscyplinowani wojskowi dopuszczali się przestępstw kryminalnych i zwykłych rabunków w dobrach, przez które przechodzili, w tym także należących do Potockich. Czynili tak zarówno żołnierze koronni, jak i litewscy, podlegli hetmanowi wielkiemu litewskiemu i wojewodzie wileńskiemu Kazimierzowi Janowi Sapieże, który starał się zabezpieczać i w pewnym sensie ochraniać te majątki, wydając odpowiednie uniwersały do podległych sobie jednostek wojskowych.

Kwestie związane ze stanem posiadania były dla Potockich niezwykle istotne, podobnie zresztą jak dla innych rodzin mających duże aspiracje polityczne i posiadających własne fakcje i stronnictwa. Do utrzymania klientów we własnym kręgu zależności i zapobiegania kurczeniu się ugrupowania niezwykle istotne były bowiem sprawy majątkowe, a dobra, dzięki którym można było utrzymać osobowy stan posiadania, a nawet go powiększać o nowych ważnych członków, były priorytetem $\mathrm{w}$ działalności każdego magnata. Zatem w tym przypadku nie dziwi, przynajmniej teoretycznie, współpraca między wymienionymi w tytule rodzinami, a na jej pierwsze symptomy można natrafić nieco wcześniej. Potoccy zaliczani byli w pierwszych latach panowania Jana III Sobieskiego do grona regalistów i stron-

${ }^{1}$ Archives Ministère des Affaires Étrangères et du Développement International République Française à Paris (dalej: AMAEF), 53 Mémoires et Documents (dalej: MD) 26, k. 192v, 196v. 
ników dworu, podobnie jak Sapiehowie 2 . Dwukrotnie podczas rządów Jana III piastowali oni urząd hetmana polnego koronnego. Najpierw godność tę sprawował Andrzej — od 1684 roku, kiedy otrzymał nominację, do śmierci 30 sierpnia lub 2 września $1691 \mathrm{roku}^{3}$. Po nim hetmanem polnym koronnym został 7 grudnia 1692 roku Feliks Kazimierz Potocki, brat zmarłego, i urząd ten obejmował do swego awansu na hetmana wielkiego koronnego, co miało miejsce 1 maja $1702 \mathrm{roku}^{4}$. Zatem z czterech hetmanów polnych koronnych za panowania Sobieskiego dwóch wywodziło się z rodu Potockich i byli to w dodatku bracia, piastujący tę godność kolejno po sobie.

Powszechnie wiadomo, że wojska litewskie pod dowództwem Kazimierza Jana Sapiehy nie dotarły do Jana III Sobieskiego pod Wiedeń i nie wzięły udziału w bitwie. Przyczyny tego są niezwykle złożone. Hetman wielki litewski nie był zwolennikiem wyprawy wojskowej przeciw Turkom. Z pewnością na takie stanowisko wpłynęły ograniczone środki finansowe, jakimi dysponował. Obradująca w Grodnie od 25 czerwca 1683 roku komisja skarbowo-wojskowa musiała się limitować właśnie ze względu na brak funduszy. Ostatecznie jednak Sapieże udało się zgromadzić wymaganą liczbę wojska pod Janowem Podlaskim, skąd powoli ruszył w kierunku Krakowa. Zastrzeżenia może budzić natomiast tempo przemieszczania się oddziałów litewskich i ich późniejsza działalność poza granicami Rzeczypospolitej. Szukając przyczyn braku udziału Kazimierza Jana Sapiehy w bitwie wiedeńskiej, należy wziąć jeszcze pod uwagę ogólną sytuację polityczną w Europie i związek hetmana wielkiego litewskiego z obcymi dworami - wersalskim i berlińskim. Pomijając tu przyczyny takiego postępowania Sapiehy — które należy rozpatrywać w wymiarze nie tylko krajowym, lecz przede wszystkim międzynarodowym - zaznaczyć należy, że stosunkowo szybko szlachta zaczęła oskarżać go o bojkotowanie rozkazów królewskich i brak obecności pod Wiedniem armii litewskiej ${ }^{5}$.

Kazimierz Jan Sapieha w okresie powiedeńskim odpierając zarzuty, starał się usprawiedliwić absencję armii Wielkiego Księstwa w powstałym najprawdopodobniej w 1683 roku diariuszu kampanii węgierskiej, którego był zapewne autorem ${ }^{6}$. Z dbałością o najdrobniejsze szczegóły opisał on przebieg walk oraz powody podjęcia określonych decyzji. Przede wszystkim jednak starał się odeprzeć ataki szlachty

2 J. STOLICKI: Rozdawnictwo wakansów przez Jana III jako metoda tworzenia partii dworskiej. W: Faworyci i opozycjoniści. Król a elity polityczne w Rzeczypospolitej XV-XVIII wieku. Red. M. Markiewicz, R. Skowron. Kraków 2006, s. 369.

${ }^{3}$ Urzędnicy centralni i nadworni Polski XIV-XVIII wieku. Spisy. Red. A. GĄsıorowsKi. Kórnik 1992, nr 158.

${ }^{4}$ Ibidem, nr 159.

${ }^{5}$ M. SAwicki: Dom Sapieżyński 1666-1685. Droga do hegemonii w Wielkim Księstwie Litewskim. Opole 2016, s. 236-238.

${ }^{6}$ Diariusz kampanii wegierskiej in anno 1683. Wyd. O. LAskowski. „Przegląd Historyczno-Wojskowy" 1933, t. 6, z. 2, s. 259-271. 
koronnej spowodowane jego nieobecnością pod murami Wiednia. Kazimierz Jan Sapieha skoncentrował się $\mathrm{w}$ swoim piśmie propagandowym przede wszystkim na opisie piętrzących się trudności, które bezpośrednio doprowadziły do absencji armii litewskiej pod stolicą państwa Habsburgów. Nie pominął również oskarżeń wobec Jana III, którego rozkazy docierały do hetmana litewskiego rzekomo zbyt późno. Jednak pierwszym i zasadniczym problemem był brak pieniędzy na wojsko i fakt, że poborcy nie chcieli ich wypłacać chorągwiom mimo asygnat hetmańskich $^{7}$. Kolejną przeszkodą w dotarciu do celu w wyznaczonym terminie było zbyt późne przybycie artylerii i piechoty oraz chorągwi jazdy, które zbierały się za wolno. Zgodnie z doniesieniami królowej Marii Kazimiery d’Arquien wojsko litewskie w ciągu tygodnia przeszło zaledwie trzy mile, co chyba jednak jest informacją nieco przesadzoną ${ }^{8}$.Znane powszechnie postępowanie podległych sobie żołnierzy wobec ludności cywilnej na terenie Węgier Sapieha tłumaczył tym, że oddziały litewskie pierwsze doświadczyły wrogości i brutalności miejscowej ludności, zwłaszcza ewangelickiej. Nie usprawiedliwiało to jednak postępowania wojskowych litewskich, którzy „ne manqua pas de brûler, de piller, de tuer sans égard; marquant sa route par des désordres epouvantables"'.

Mimo tego publicznie posunięć wojskowych Kazimierza Jana Sapiehy bronił w swej korespondencji propagandowej kasztelan krakowski Andrzej (Jędrzej) Potocki, który w dokumencie z 28 grudnia 1684 roku skierowanym do arcybiskupa gnieźnieńskiego nawiązał do wcześniejszych wydarzeń militarnych. Twierdził on, że hetman wielki litewski niewielkimi siłami był w stanie zadać nieprzyjacielowi poważne straty bez uszczerbku własnych jednostek, co miało chyba wskazywać na niezwykłe, choć nie do końca zgodne z rzeczywistością, umiejętności dowódcze hetmana wielkiego litewskiego: „[...] Pan Hetman Wielki Xielkiego Księstwa Litewskiego zostawszy się z kilką chorągwi i regimentem barzo niewielą, wszystkimi ostatnim nieprzyjacielskim siłom wywartym ingenti gloria nominis sui dał odpór, bez żadnej straty ludzi a z znaczą nieprzyjaciela konfuzyą [...]"10.

W piśmie propagandowym Andrzeja Potockiego, raczej o niewielkim zasięgu, obrona wojewody wileńskiego nastąpiła zaraz po nawiązaniu do niepowodzeń wojennych Jana III Sobieskiego, co bezpośrednio uderzało w monarchę. Nie trzeba

7 A. Czarniecka: Nikt nie stucha mnie za życia... Jan III Sobieski w walce z opozycyjna propaganda (1684-1696). Warszawa 2009, s. 115-116; Diariusz kampanii wegierskiej in anno 1683..., s. 261.

${ }^{8}$ A. Czarniecka: Nikt nie stucha mnie za życia..., s. 116-117; O. Forst de Battaglia: Jan Sobieski, król Polski. Tłum. K. SzyszkowsKa. Warszawa 1983, s. 248-249.

${ }^{9}$ Cyt. za: O. Forst de Battaglia: Jan Sobieski król Polski..., s. 249.

${ }^{10}$ List Jmści Pana Krakowskiego Jędrzeja Potockiego do Xięcia Jmści Xiędza Arcybiskupa Gnieźnieńskiego Stef. Wydżgi pisany ze Lwowa d. 28 Decembris 1684 r. W: Pomniki dziejów Polski wieku siedemnastego. T. 2. Wyd. A. Podgórski. Wrocław 1840; A. Czarniecka: Nikt nie stucha mnie za życia..., s. 127. 
było długo czekać na rewanż ze strony Kazimierza Jana Sapiehy. Już kilka miesięcy po pojawieniu się wzmiankowanego listu wziął on pod ochronę dobra owruckie Potockich. Traktuje o tym pierwszy ze znanych mi uniwersałów hetmana wielkiego litewskiego - z Warszawy z 15 kwietnia 1685 roku. Jest to ordynans, który do ksiąg grodzkich owruckich wpisał łowczy bracławski Jan Antoni Potocki. Był on adresowany do marszałka starodubowskiego Andrzeja Kierły, któremu hetman wielki litewski Kazimierz Jan nakazywał, aby wraz ze swoją chorągwią natychmiast wymaszerował z dwóch wsi: Bowsunów i Moszków, leżących w starostwie owruckim i należących do tamtejszego starosty Franciszka Potockiego ${ }^{11}$.

Hetman wielki litewski już od początku roku próbował odpowiednimi uniwersałami zdyscyplinować wojsko znajdujące się na terenach Ukrainy, nie tylko w dobrach należących do Potockich. Doszło bowiem wtedy do incydentu związanego z chorągwią podczaszego wielkiego litewskiego Jana Karola Dolskiego, dowodzoną przez niewymienionego $\mathrm{z}$ imienia Wieliczkę, która wbrew rozkazom przez dwa tygodnie stacjonowała w dobrach zwanych Kniechinin, należących do Jezuitów Kolegium Ostrogskiego. Sapieha nakazywał, aby nie oddając tej sprawy przed jego sąd hetmański, załatwić ją polubownie i wynagrodzić poddanym tamtejszym i właścicielom ziemskim wszystkie wyrządzone podczas postoju chorągwi szkody. Wzmiankowanym dowódcą mógł być zaufany oficer sapieżyński Teodor Wieliczko ${ }^{12}$.

Zdarzeń takich musiało być jednak znacznie więcej, skoro Kazimierz Jan Sapieha zdecydował się wydać ogólny i stanowczy zarazem uniwersał do wojska stacjonującego na północy Ukrainy, który został wpisany do ksiąg grodzkich owruckich. Postanowienia hetmańskie dotyczyły województwa kijowskiego - powiatów owruckiego i żytomierskiego. Hetman nakazywał, aby wojsko postępowało w sposób jak najmniej uciążliwy dla mieszkańców i nie wywoływało „zbyteczne[go] uciążenia poddanych $\mathrm{z}$ ruiną dóbr i niewygody ichmościów panów posesorów tamecznych". Taka reakcja dowodzącego armią litewską wynikała z częstych skarg właścicieli tamtejszych majątków, sąsiadujących przecież z ziemiami litewskimi, na poważne szkody wyrządzone przez oddziały wojskowe. Sapieha nawiązując do kilkukrotnego już upominania żołnierzy i dowódców, stanowczo nakazywał, aby „żadna chorągiew tak polskiego jako i cudzoziemskiego zaciągu i żaden żołnierz nie ważył się takich czynić exactij i ucisków, ale raz już wziętą kontentował się statią, pieniędzy nie wyciągał, poddanych nie uciążał i żadnej najmniejszej nie czynił krzywdy, ale jako najskromniej zachowywał się, obawiając się sądu i srogiego bez respectu karania $[\ldots]]^{\prime 13}$.

${ }^{11}$ Centralnij dierżawnij istoricznij archiw Ukraini, Kijów (dalej: CDIAU), f. 15, op. 1, nr 4, k. 33-33v, Uniwersał K.J. Sapiehy, Warszawa 15 kwietnia 1685.

12 Ibidem, k. 22v-23; M. SAw ICKi: Dom Sapieżyński 1666-1685..., s. 113.

${ }^{13}$ CDIAU, f. 15, op. 1, nr 4, k. 23v-24v, Uniwersał K.J. Sapiehy, Słonim 8 lutego 1685. 
Wojewoda wileński zlecił także niewymienionemu $\mathrm{z}$ imienia i nazwiska regimentarzowi dopilnowanie kwestii związanych z sądzeniem żołnierzy winnych przestępstw na ludności cywilnej i przedstawianie odpowiednich wniosków do sądu hetmańskiego. Ze swojej strony hetman wielki litewski zapewnił, że będzie surowo i bezwzględnie karał wszystkich winnych grabieży czy też innych przestępstw pospolitych $^{14}$. W kolejnym uniwersale Kazimierz Jan Sapieha zabronił wojsku wybierania niezgodnych z prawem chlebów zimowych oraz stwarzania problemów związanych $\mathrm{z}$,noclegami i przechodami”. Nieprzestrzeganie tych zasad groziło poważnymi konsekwencjami prawnymi, choć $\mathrm{z}$ ich egzekwowaniem bywało różnie ${ }^{15}$. Jak widać na przytoczonych przykładach związanych z dobrami Potockich, wszelkie tego typu zarządzenia hetmańskie nie były w pełni respektowane przez przemieszczające się lub stacjonujące tam jednostki wojskowe i - mimo ich restrykcyjności - żołnierze nadal nie przestrzegali istniejącego prawa.

Kolejnym dokumentem sapieżyńskim dotyczącym ochrony majątków Potockich, co jak widać było konieczne, ale w rzeczywistości raczej mało skuteczne, jest uniwersał Kazimierza Jana Sapiehy wydany w obozie pod Lipowcami 22 września 1687 roku. I tym razem dotyczył on dóbr starosty owruckiego Franciszka Potockiego. W piśmie tym hetman wielki litewski zgodnie $\mathrm{z}$ obowiązującym prawem oznajmiał: „,ich mściom panom oficjalistom wojskowym i całemu in genere rycerstwu wojsk jego Kr[ólewskiej] Mści Wielkiego Księstwa Litewskiego tak polskiego jako i cudzoziemskiego zaciągu chęci moje oznajmuję, iż stosując się do prawa pospolitego, które dobra ziemskie ab omni uwalniają onere militari, daję ten ochronny uniwersał na dobra wielmożnego jm pana Franciszka Potockiego, starosty owruckiego, dziedziczne miasteczko Wieledniki cum attinentis, które to pomienione dobra, jako moje własne mieć chcę w ochronie, $[\ldots]^{\prime 16}$.

Sapieha zabronił jakichkolwiek przemarszów, noclegów, popisów, wybierania "ugód zimowych" pod groźbą wyciągnięcia dotkliwych konsekwencji wynikających z przysługującego mu prawa ${ }^{17}$.

Surowe rozkazy hetmańskie po raz kolejny nie przyniosły jednak żadnych rezultatów i w następnym roku dowodzący armią litewską ponownie musiał występować w obronie dóbr ziemskich szlachty kijowskiej i wołyńskiej w związku z wojskiem przebywającym tam na leżach zimowych. Po wizycie posłów, przybyłych zapewne ze skargą na stacjonujące tam jednostki, Sapieha zdecydował się wyznaczyć sędziego wojskowego wraz z komisarzami, którzy mieli zlustrować tamtejsze dobra i przeprowadzić śledztwo pod kątem szkód, jakie wyrządzili żołnierze. Niestety nie wy-

${ }^{14}$ Ibidem, k. 24v.

${ }_{15}$ Ibidem, k. 25v, Uniwersał K.J. Sapiehy, Słonim 9 lutego 1685.

${ }^{16}$ Ibidem, nr 5, k. 281-281v, Uniwersał K.J. Sapiehy, w obozie pod Lipowcami 22 września 1687.

${ }^{17}$ Ibidem, k. 281v. 
mieniono w tym przypadku nazwisk wysłanych przez Kazimierza Jana urzędników wojskowych. W dokumencie zaznaczono, że wszelkie stwierdzone straty zostaną naprawione, a winni - należycie ukarani ${ }^{18}$.

Działania hetmana wielkiego litewskiego dotyczące tak stanowczej ochrony dóbr owruckich należących do Potockich nie były bezpodstawne, a zniszczeń dopuszczali się również żołnierze chorągwi należących do innych dygnitarzy litewskich, w tym kanclerza wielkiego Marcjana Aleksandra Ogińskiego. W tym przypadku przestępstw dopuściły się oddziały cudzoziemskie. W związku z tym sporządzono rejestr szkód, a w imieniu starosty Franciszka Potockiego w charakterze świadków wystąpili: burmistrz miasta Owrucza Stefan Onoszka, mieszczanin Wasyl Drozda oraz bojarzyn Andrzej Szwaba. Wydarzenia, o których mieli poinformować, obejmowały okres od 7 listopada 1687 roku aż do 13 czerwca 1688 roku, czyli 31 tygodni, w czasie których jednostki litewskie stacjonowały w wymienionych dobrach. Rabunków, zniszczeń i grabieży dopuścili się żołnierze pod dowództwem kapitana królewskiego Krzysztofa Przyborowskiego, chorążego królewskiego Jana Hawdrynga, „kaptenarmusa” Jana Szczeblewskiego oraz podchorążego Jana Kochanowskiego. Dowodzili oni w sumie sześcioma rotami, które dopuściły się największych przestępstw i zniszczeń w starostwie owruckim. Działania żołnierzy, poza szkodami natury społecznej, miały realny, finansowy wymiar. Zniszczono na przykład zapas półproduktów służących do ważenia piwa w miejscowej karczmie, którą wcześniej obrabowano z alkoholu, a miejscowym wojskowi kazali kupować sobie gorzałkę i miód. Pierwszy z wymienionych napitków kosztował "kwarta po groszy dwunastu”, a drugi - garniec „rachując po groszy dwudziestu". Podczas rabunku alkoholu chorąży królewski Hawdryn pobił miejscowego dzierżawcę, nie oszczędzając jego żony i syna, którzy także zostali mocno poturbowani: „razów sinich spuchłych krwią ociekłych niemało nazadawał”. Żołnierze zrabowali także srebra, w tym zastawy stołowe, i dalej „instrumenta złotnickie, kociołki, cynę mosiądz" za kwotę 50 zł. W sumie miasto Owrucz oszacowało straty na $4476 \mathrm{zl}$, nie wliczając do tego przyległości i wsi znajdujących się w starostwie, w których jednostki wojskowe także wyrządziły wymierne i duże szkody ${ }^{19}$.

Niestety również chorągwie samego hetmana wielkiego litewskiego Kazimierza Jana Sapiehy dopuściły się w starostwie owruckim łamania obowiązującego prawa i zwyczajnych, pospolitych grabieży, co skończyło się wniesieniem odpowiedniego protestu do organów administracji państwowej. Szkody wyrządziły chorągwie petyhorskie Kazimierza Jana Sapiehy oraz strażnika wielkiego litewskiego, klienta sapieżyńskiego Samuela Kmicica w dobrach starostwa owruckiego, we wsiach Szo-

\footnotetext{
${ }^{18}$ Ibidem, nr 6, k. 26-26v, Uniwersał K.J. Sapiehy, Grodno 7 marca 1688.

${ }^{19}$ Ibidem, k. 75v-85v, Rejestr szkód chorągwi litewskich M.A. Ogińskiego w starostwie owruckim.
} 
łomka, Obychody i Wystupowicze - wszystkie należące do stolnika żytomierskiego Remigiana Juryna ${ }^{20}$.

Kazimierz Jan Sapieha również w latach 90. XVII wieku interweniował w sprawie starostwa owruckiego, co świadczyło o nikłej skuteczności wojskowego aparatu sprawiedliwości. Dowodziło to także niewielkiej dyscypliny panującej w wojsku i być może nie tyle nieskutecznych, ile nieodstraszających kar. Tym razem hetman wielki litewski wydał ordynans „z pieczęciami dwiema i podpisem ręki własnej” nakazujący natychmiastowy wymarsz z wymienionych dóbr stolnika żytomierskiego dwóch chorągwi tatarskich: jednej kasztelana wileńskiego i hetmana polnego litewskiego Józefa Bogusława Słuszki, a drugiej podkanclerzego litewskiego Karola Stanisława Radziwiłła. Pierwsza z nich znajdowała się we włości wielednickiej, a druga - norzyńskiej. Hetman z całą stanowczością stwierdził w dokumencie, że wymienione dobra nigdy nie wchodziły w skład majątków, którymi dysponowano na potrzeby wojska, a znajdujące się tam oddziały znalazły się w nich bez wiedzy i przyzwolenia Kazimierza Jana Sapiehy. Nakazał on również pokryć wszystkie straty, a w razie niewykonania polecenia zastrzegał, że wymierzy kary przewidziane prawem, włączając $\mathrm{w}$ to również karę śmierci. Nakazał także przemieszczenie się wymienionych jednostek do dóbr metropolii i archimandrii kijowskiej, gdzie żołnierze nie mają dopuszczać się żadnych przestępstw - czy to na tle społecznym, czy zwyczajnym, rabunkowym ${ }^{21}$.

Zabiegi hetmana litewskiego i wojewody wileńskiego nie przyniosły zapewne oczekiwanych rezultatów, a stacjonowanie wojsk w dobrach rodziny Potockich musiało im przynieść - i zapewne przyniosło - niemałe szkody. Do tego dodać należy straty ekonomiczne poniesione w wyniku działań wojennych na Ukrainie. W maju 1694 roku Melchior de Polignac donosił do Wersalu, że Turcy i Tatarzy zamierzają najechać na Podole i Ruś, co zapewne bezpośrednio narażało dobra Potockich na wymierne straty finansowe $e^{22}$. Rok później na działania un grande corpus de Tartares skarżył się kasztelan krakowski Stanisław Jan Jabłonowski. Musiały być one do tego stopnia uciążliwe, że M. de Polignac nadmienił o nich nawet w liście do Ludwika XIV ${ }^{23}$. Wszystkie tego typu działania, a także konieczność utrzymywania na omawianym terenie państwowych jednostek wojskowych narażały dobra prywatne na duże straty finansowe, które najczęściej nigdy nie były rekompensowane w całości. O zniszczeniach tych wspominają nawet wysłannicy Ludwika XIV, którzy niejednokrotnie podkreślali w swych relacjach ruinę majątkową poszczególnych rodzin magnackich posiadających dobra na Ukrainie dotkniętej jeśli nie działaniami

${ }^{20}$ Ibidem, k. 86.

${ }^{21}$ Ibidem, nr 8, k. 16v-17, Uniwersał K.J. Sapiehy, Grodno 8 lutego 1693.

${ }^{22}$ AMAEF, Correspondance politique Pologne (dalej: CP Pologne) 90, k. 222, Raport ambasadora Melchiora de Polignac, Żółkiew 12 maja 1694.

${ }^{23}$ AMAEF, CP Pologne 87, k. 547, Raport ambasadora Melchiora de Polignac, Warszawa 9 października 1695. 
wojennymi, to nieustannymi przemarszami różnych jednostek. Tak było również w przypadku rodziny Potockich, o której informowali dyplomaci francuscy, podkreślając i może nieco wyolbrzymiając poniesione przez nią straty majątkowe ${ }^{24}$.

Hetman wielki litewski Kazimierz Jan Sapieha mimo stanowczości wyrażanej $\mathrm{w}$ analizowanych ordynansach nie był w stanie zapobiec dewastacji dóbr starostwa owruckiego Franciszka Potockiego, mimo że prawdopodobnie żołnierze dopuszczający się przestępstw na jego terenie byli karani przez sądy hetmańskie, zgodnie z obowiązującym prawem. Takie przynajmniej były założenia teoretyczne, które jednak czasem znacznie odbiegały od praktyki. Trudno chyba było Sapieże ukarać wojskowych będących w chorągwiach jego zajadłego przeciwnika politycznego, dodatkowo wspieranego przez dwór królewski, hetmana polnego litewskiego Józefa Bogusława Słuszki albo swoich oddanych oficerów, którzy funkcjonowali w fakcji wojewody wileńskiego. Mimo tego Sapieha próbował chronić starostwo owruckie od ciężarów wojskowych, co wpisywało się we współpracę między rodzinami Sapiehów i Potockich. Pierwsi szukali poparcia wśród wpływowych Koroniarzy wobec coraz większej i stopniowo agresywniejszej opozycji w Wielkim Księstwie, wspieranej przez Marię Kazimierę d’Arquien i jej męża Jana III Sobieskiego. Drudzy natomiast zapewne z obawą obserwowali narodziny na Litwie ruchu republikanckiego, zagrażającego nie tylko Sapiehom, ale mogącego skutecznie przeszczepić swoje postulaty w Koronie. Nie bez znaczenia był chyba również wymiar solidarności wśród magnaterii dawnej Rzeczypospolitej. Oczywiście podjęta tu tematyka wymaga jeszcze szczegółowych badań, a niniejszy tekst stanowi jedynie niewielki jej zarys.

\section{Bibliografia}

CzARnIECKa A.: Nikt nie stucha mnie za życia... Jan III Sobieski w walce $z$ opozycyjna propaganda (1684-1696). Warszawa 2009.

Diariusz kampanii węgierskiej in anno 1683. Wyd. O. LAskowski. „Przegląd Historyczno-Wojskowy” 1933 , t. 6, z. 2, s. 259-271.

Forst de Battaglia O.: Jan Sobieski, król Polski. Tłum. K. Szyszkowska. Warszawa 1983.

List Jmści Pana Krakowskiego Jędrzeja Potockiego do Xięcia Jmści Xiędza Arcybiskupa Gnieźnieńskiego Stef. Wydżgi pisany ze Lwowa d. 28 Decembris 1684 r. W: Pomniki dziejów Polski wieku siedemnastego. T. 2. Wyd. A. Podgórski. Wrocław 1840.

SaWicki M.: Dom Sapieżyński 1666-1685. Droga do hegemonii w Wielkim Księstwie Litewskim. Opole 2016.

${ }^{24} \mathrm{~W}$ tym przypadku warto zwrócić uwagę na raporty znajdujące się w AMAEF, CP Pologne pod numerem 87, gdzie w prawie każdym raporcie, w którym omawiane były kwestie wojenne, dyplomaci nawiązywali w sposób bezpośredni i pośredni do ruiny gospodarczej terenów objętych działaniami militarnymi, wskazując na duże straty materialne, jakie poniosły rodziny zamieszkujące ten obszar. 
STOLICKI J.: Rozdawnictwo wakansów przez Jana III jako metoda tworzenia partii dworskiej. W: Faworyci i opozycjoniści. Król a elity polityczne w Rzeczypospolitej XV-XVIII wieku. Red. M. Markiewicz, R. SKowron. Kraków 2006.

Urzędnicy centralni i nadworni Polski XIV-XVIII wieku. Spisy. Red. A. GĄsıorowski. Kórnik 1992, nr 158.

Mariusz Sawicki

The Sapiehas' protection of the Potockis' estates and possessions in the Owrucz starostwo in 1680s and 90s

An introductory study on the magnate families' cooperation during the reign of John III Sobieski

Summary

The Sapiehas and the Potockis were amongst the most influential families of the Polish-Lithuanian Commonwealth. The latter family owned numerous estates in Ukraine, which were directly under threat from marching Lithuanian soldiers. Kazimierz Jan Sapieha, Grand Hetman of Lithuania was in charge of the said estates. Due to cooperation of the two magnate families, he attempted to shield the Potockis' estates and possessions from Lithuanian troops marching to or returning from the war with Turkey. To that aim he utilised legal proclamations called Universals. The Potockis returned the favour by entering into political collaboration. Hetman Kazimierz Jan Sapieha, having been absent from the Siege of Vienna, had to incur accusations and attacks during Sejm proceedings. He was then (1684) defended in a propaganda letter by Andrzej Potocki, Castellan of Kraków. The research themes analysed in the article serve as both, an introductory outline and a voice in the discussion regarding cooperation of Lithuanian and Polish noble families in the second half of the 17th century.

Key words: Sapiehas, Potockis, estates and possessions, Ukraine, soldiers 